\title{
RISK FACTORS OF SHORT-FAT STATUS NUTRITION AMONG CHILDREN AGED 12-23 MONTHS IN INDONESIA
}

\author{
Imtihanatun Najahah ${ }^{1}$, Linda Meliati ${ }^{1}$ and Mutiara Rahmawati Suseno ${ }^{1}$ \\ ${ }^{1}$ Midwifery Departement, Health Polytechnic Ministry of Mataram, West Nusa Tenggara, Indonesia \\ Corresponding author: Imtihanatun Najahah ${ }^{1}$ \\ Email: imtihanatun80@gmail.com
}

\begin{abstract}
Indonesia has a double burden, which is besides facing the problem of malnutrition and other micronutrient deficiencies, Indonesia also faced the problem of obesity. Prevalence of short-fat status nutrition in Indonesia amounted to $6.8 \%$ in 2013. This study aimed at determining the risk factors for short-fat status nutrition in children aged 12-23 months in Indonesia. The design of this study was a cross-sectional study using secondary data from basic health Research (RISKESDAS) 2013, with a sample size of 378,308 children aged 12-23 months. the dependent variable in this study is short-fat nutrition status and the independent variables are exclusive breastfeeding, complementary feeding, neonatal visit, immunization, and Giving of Vitamin A. Further analysis of the data in several steps include univariate, bivariate (chi -Square), and multivariate (logistic regression). Sample of this study is mostly male 204,030 (53.9\%) with the nutritional status based on the combined height/age and weight/ height is not shot-fat status nutrition 352450 (93.2\%). Based on bivariate test results, four variables are to be the risk factors in this study, are not exclusive breastfeeding OR $=1.047$, Complementary food OR $=1.136$, immunization $O R=0.761$, and vitamin $A$ consumption $O R=0.601$. While the neonatal care visits variable as the risk factor. Multivariate analysis showed that the most dominant variable is the provision of complementary food OR 1.158 (95\% Cl 1.127 to 1.189). From these results, it can be concluded that giving complementary feeding is the most responsible for the short-fat nutrition status in children aged 12-23 months. Prevention efforts need to through monitoring the nutritional status of children, especially monitoring the growth of body length or height by age as early as possible for early detection of nutritional problems in children, so that management can quickly prevent that case.
\end{abstract}

Keywords: Children aged 12-23 months, short-fat nutrition status, risk factors

\section{INTRODUCTION}

In Indonesia, there are still problems in mothers and children, marked by the height of maternal mortality and infant mortality, the prevalence of Undernutrition (Weight of Body/Age (WB/A) with Zscore <-2SD and Shorts (Height of Body/Age (HB/A) with Z-score (HAZ) below the median by more than minus two standard deviations (<-2SD) and deficiency of vitamin $A$ in children under 5 years of age is still high and Indonesia faces a double burden of malnutrition with an increasing prevalence of overweight children ${ }^{1}$. In Indonesia, the prevalence of overweight in 2007 of $12.2 \%$ increased to $14.0 \%$ in 2010 and increased in 2013 by $11.9 \%$. Overweight problems at an early age may cause a risk of a variety of degenerative diseases during adulthood, according to the Barker theory ${ }^{2}$, and the prevalence of stunting in children under five years of age nationwide increased from previous years, in the year 2007 by $36.7 \%$, in 2010 of $35.7 \%$ and 2013 increased to $37.2 \%$. Short-fat nutrition status is nutrition status combined Height of Body/Age and Weight of Body/ Height of Body (HB/A and WB/HB) with indicator Z-Score $\geq-2,0$ to Z-Score $\leq 2,0$, it's one of nutrition status by Combined Indicator HB/A and WB/HB. Prevalence Trends of Nutrition Status of Children under Five Years of Age by Combined Indicator $\mathrm{HB} / \mathrm{A}$ and $\mathrm{WB} / \mathrm{HB}$, Indonesia 2007, 2010, and 2013 for short-fat nutrition status were $7.4 \%$, $7.6 \%$, and $6.8 \%{ }^{2}$.

Short-fat nutrition status is a problem related to child growth, the cause of this problem according to UNICEF, ${ }^{3}$ is caused by two factors, namely direct cause, and indirect cause. Nutritional intake is needed in the continuation of the child's growth process when the newborn is the best nutritional intake of breast milk since breast milk contains nutrients needed by infants according to the nutritional needs of infants according to their age. Kramer \& Kakuma In 2004 reiterated the evidence of the exclusive breastfeeding influence on the health and growth of infants reveals that infants who obtain exclusive breast milk for up to six months have low pain rates on digestive and allergic diseases ${ }^{4}$. So that the only milk given to infants in addition to fulfilling their nutritional needs can also prevent babies from getting sick which is a direct factor in the growing baby the nutritional needs of infants for optimal growth so that a companion meal complimentary food is needed to complement the 
nutritional needs of infants. This complimentary food is starting to be administered to infants aged 6 months because if the infant is only given breast milk only after six months age will only meet about $60 \%-70 \%$ of infant needs. While the $30 \%-40 \%$ must be fulfilled from a companion or supplementary meal. Administration of complementary food should begin when the infant is six months old because before the age of six months, the digestive enzymes of babies have not been perfect so that infants cannot digest flour and yet Perfectly digest proteins in addition to the intestinal immune system has not been perfect, consequently, the enzyme that functions to coat food proteins allergic causes has not been sufficiently produced, so that the proteins that enter the intestinal cells instead stimulate allergic reactions and Intolerance and at the age of six months is when the baby begins to learn to chew and swallow solid food so that the risk of choking becomes reduced. At the age of 6-12 months of breast milk only provides half or more nutritional needs of infants, entering the age of 12-24 months of breast milk only provides a third of its nutritional needs, for that baby needs to get complimentary food to meet the need for a nutrient body ${ }^{5}$.

The role of nutrient intake is very important to note because if it is not correct in its delivery can cause nutritional deficiencies or excess nutrients due to the increase of body weight and fat is influenced by the first time get food Dense, the high-calorie intake of carbohydrates and fats ${ }^{6}$. Health care in mothers and infants is also an important factor in the incidence of nutritional problems such as research conducted in Brazil that produces the results of the prevalence of short-term childhood research decreased by more than 30 percent, which is from 37 percent in 1974 to 7 percent in 2006, by doing four priority handling one of which is access to sustainable health and nutrition services in mothers and children. The child health Service in Indonesia is initiated from a neonatal visit given by the health officer, then the service in the form of vitamin A-giving service and immunization administration. Neonatal visit service is a health service in infants that aims to increase neonatal access to basic health services also to know as early as possible if there is a health disorder/problem in neonatal 1 , and on this neonatal visit infants get immunization and there are counseling activities on mothers and families about the exclusive feeding of the Problems with baby growth. In Indonesia, the complete neonatal visit (KN) coverage increased from 31.8 percent in 2007 to 39.3 percent in 2013 2 .

Immunization is one of the attempts to avoid or prevent any illness or occurrence that causes a person to be sick or suffer injuries and defects that can inhibit the child's growth ${ }^{3}$. so that doing health services in a child in the form of immunization can prevent the problem of development especially nutritional problems in children. In Indonesia, complete immunization coverage experienced an enhancer from 41.6 percent in 2007 to 59.2 percent in $2013^{2}$.

Vitamin A plays A role in maintaining the normal growth of cells, regulates proliferation, and the differentiation of epithelial tissues, (Goodman,1984), so that if a child is experienced with vitamin A will be able to inhibit its growth so that the health service efforts of one's children by administering of vitamin A. In Indonesia, scope of giving of vitamin A capsules has increased from 71.5 percent in 2007 to 75.5 percent in $2013^{2}$. Vitamin A Nutritional problems can inhibit the growth of children, with the negative impact that will take place in the next life ${ }^{4}$, so it is expected when a child of a baby is born when getting exclusive breast milk and subsequently get an intake of MPASI nutrients when the baby is 6 months old, then the baby gets $A$ child health service in the form of neonatal visit continuously when he aged $0-28$ Critical is expected that the baby does not have a problem of growth or a fat short nutritional problem. In the survey described here, risk factors for short-fat status nutrition of children aged 12-23 months in Indonesia.

\section{METHODS}

The study designs an analytical cross-sectional study was conducted using secondary data from basic health Research (RISKESDAS) 2013. This study is a further analysis of the data Riskesdas 2013. Processing, analysis, and interpretation of data were conducted in October 2014 at the campus of Politeknik Kesehatan Mataram. The population in this study is: children age 12 - 59 months in Indonesia and the sample in this study is children age 12-23 months in Indonesia which has a sample of 378,308 in 2013 after using cleaning and multistage techniques process. The measured variables are dependent variables and independent variables. The dependent variable is the combination short- fat status nutrition of a child aged 12-23 months and the independent variable consist of exclusive breastfeeding, complementary feeding, neonatal visit, immunization status, vitamin A capsule distribution coverage. The Data obtained and collected will be analyzed by using Microsoft Excel 2007 for Windows and All analyses were performed using the software SPSS 15.0 (IBM Corporation, NY, USA). The first Data processing phase is coding, cleaning, and editing of existing data than selected based on variables to be researched and carried out multicollinearity tests.

The prevalence Data of all variables is attributed to two categories. Short-fat nutrition status is 
nutrition status combined Heigh of Body/Age and Weight of Body/ Height of Body (HB/A and WB/HB) with indicator Zscore $\geq-2,0$ to Zscore $\leq 2,0$, and its categories are short-fat nutrition status and not short-fat nutrition status. exclusive breastfeeding is only available in infants without any additional food provided starting from baby birth Until the baby is 6 months old, for his assessment is a toddler with exclusive breast milk if the toddler gets breast milk only without additional food from birth to 6 months and the baby is not exclusive milk is a baby who does not get breast milk alone or ever get additional food from birth to 6 months. Complementary feeding is a type of food given to infants other than breast milk. Assessment is the provision of complementary food $\geq 6$ months and the administration of $<6$ months. The neonatal visit is data of neonatal visits when the newborns reach aged 6-48 hours (first Neonatal Visit), 3-7 days (second Neonatal Visit), and 8-28 days (Third Neonatal Visit), for the assessment is a newborn with a complete Neonatal Visit if the newborn visits or visited by three visits by the schedule of visits, and Neonatal Visit not complete if the newborns never make visits/visit or make visits less than twice during the neonatal period. Immunization status is a provision of immunizations that includes immunization one-time HB-0, one time BCG, three times DPT-HB, four-time polio, and one-time measles immunization, for the assessment is a toddler with complete immunization when already obtained all types of immunizations one-time HB-0, one time BCG, three times DPT, four times polio, and one-time measles immunization and immunization is incomplete if the toddler never gets immunization. Vitamin A capsule distribution coverage is administering vitamin A capsules which are given a year twice in February and August since the child is six months old. For the assessment is the child by obtaining vitamin $A$ is a child who once gained vitamin $A$ and the category that does not get vitamin $A$ is a child who never gets vitamin $A$.

Data analysis is done by univariate to view the frequency distribution of each variable and continued with bivariate analysis to see the relationship between the dependent variables with the independent variable, this relationship test used the chi-square test. While multivariate analysis using a regression test logistic method
Enter to look for risk factors that are dominant increases the risk of combination short-fat nutrition status is done against a variable with a value $\mathrm{P}$ of $<$ 0.25 of the Bivariate analysis results.

\section{RESULTS}

The number of samples 378,308 children age $12-23$ months in Indonesia. Most participants were male (204030; 53.9\%), no combination short-fat nutrition status (352450; 93.2\%), exclusive breastfeeding ilk $(254,345 ; 67.2 \%)$, get complementary feeding of $<6$ months $(234320 ; 61.9 \%)$, complete neonatal visit $(378,308 ; 100 \%)$, Complete immunization status $(326,588 ; 86.3 \%)$ and get vitamin A $(332,808 ; 88 \%)$.

Analytical bivariate results there are four variables showed was significantly associated with short-fat nutrition status consist of the exclusive breastfeeding, complementary feeding, immunization status, and vitamin A capsule distribution coverage as presented in table 1 . The relationship between exclusive breast milk with short-grease in children aged 12-23 months from the results of the cross-table analysis showed a combination short-fat nutrition status in children aged 12-23 months proportion higher in children with no exclusive breastfeeding than the child with exclusive breastfeeding of $7.0 \%$ and $6.7 \%$. Analytical analysis the exclusive breastfeeding was significantly associated with short-fat nutrition status ( $p$-value < 0.05) which means the more children are given the exclusive breastfeeding can preventing of children with short-fat nutrition status, with the value $O R=1,047$. Analytical bivariate complementary feeding was significantly associated with short-fat nutrition status ( $p$-value $<0.05$ ) with value $O R=1,136$, immunization status was significantly associated with short-fat nutrition status ( $p$-value $<0.05)$ with value $O R==0,761$ which means the child who gets the complete immunization can preventing short-fat nutrition status in children age 12-23 month and administration of vitamin A capsule was significantly associated with short-fat nutrition status $(p$-value $<0.05)$ with value $O R==0,601$. From sufficient analysis, four variables have a value of $p<0.25$, then analyzed in a multivariate, so as in Table 2. 
Table 1. Results of a bivariate analysis of fat short risk factors in children aged 12-36 months in Indonesia.

\begin{tabular}{|c|c|c|c|c|c|}
\hline Variable & $\begin{array}{l}\text { Short-Fat } \\
\text { Nutrition } \\
\text { Status } \\
(\mathrm{n}=25859)\end{array}$ & $\begin{array}{l}\text { Not short- } \\
\text { fat Nutrition } \\
\text { Status } \\
(n=352450)\end{array}$ & OR & $\mathrm{Cl} 95 \%$ & $\begin{array}{l}p- \\
\text { value }\end{array}$ \\
\hline \multicolumn{6}{|c|}{ Exclusive Breastfeeding } \\
\hline No & $8720(7,0)$ & $115243(93,0)$ & 1,047 & $1.020-1.076$ & 0,001 \\
\hline Yes & $17138(6,7)$ & $237206(93,3)$ & & & \\
\hline \multicolumn{6}{|c|}{ Complementary feeding } \\
\hline$<6$ month & $16730(7,1)$ & $217590(92,9)$ & 1,136 & $1.106-1.166$ & 0,000 \\
\hline$\geq 6$ month & $9128(6,3)$ & $134860(93,7)$ & & & \\
\hline \multicolumn{6}{|c|}{ Immunization Status } \\
\hline uncomplete & $2825(5,5)$ & $48895(94,5)$ & 0,761 & $0.731-.793$ & 0,000 \\
\hline Complete & $23033(7,1)$ & $303555(92,9)$ & & & \\
\hline \multicolumn{6}{|c|}{ Giving of Vitamin A } \\
\hline No & $2018(4,4)$ & $43482(95,6)$ & 0,601 & $0.574-0.630$ & 0,000 \\
\hline Yes & $23840(7,2)$ & $308968(92,8)$ & & & \\
\hline
\end{tabular}

Table 2. Analysis results of logistic regression short-fat nutrition status risk factors in children age 12-23 months in Indonesia

\begin{tabular}{lllll}
\hline \multirow{2}{*}{ Independent Variable } & \multirow{2}{*}{ p-value } & OR & \multicolumn{2}{l}{$95,0 \%$ C.I.for EXP(B) } \\
\cline { 5 - 5 } & & & Lower & Upper \\
\hline Breastfeeding Exclusive & 0,001 & 1,049 & 1,021 & 1,078 \\
Complementary Feeding & 0,000 & 1,158 & 1,127 & 1,189 \\
Immunization Status & 0,000 & 0,780 & 0,749 & 0,812 \\
Giving of Vitamin A capsule & 0,000 & 0,613 & 0,585 & 0,643 \\
\hline
\end{tabular}

R square $=0,005$

The table above shows the variables in the dominant role of increasing the fat short risk in children aged 12-23 months in Indonesia are exclusive breastfeeding, complementary feeding, immunization status, and giving of vitamin A capsule. These four variables are instrumental to short-fat nutrition status events of $5 \%$.

\section{DISCUSSION}

In this research the exclusive breastfeeding, complementary feeding, immunization status, and the giving of vitamin A capsule as risk factors for short-fat nutrition status children age 12-23 months in Indonesia. The provision of breast milk should be given for two years to support children's growth and development. A study conducted in a slum area in Addis Ababa also showed that there is a significant relationship between the duration of breastfeeding and stunting. Studies in the last two decades have increasingly shown that breast milk is the best and most complete nutrient. Breast milk is the ideal nutrient to support the health, growth, and development of the baby optimally ${ }^{10}$. This study showed that children who did not get exclusive breast milk had a higher proportion of short-fat, which was $7.0 \%$ compared to children who had exclusive breast milk of $6.7 \%$. Based on statistical test results there is a meaningful relationship between the exclusive breast milk with short fat in children aged $12-23$ months $(P<0.05)$ with value $O R$ $=1.047$ so exclusive breast milk is a fat short risk factor in children aged 12-23 months.

The results showed similar results to the research done at Ethiopian West Gojam about stunting determinants. The results showed that there was a significant link between the duration of the breastfeeding and the stunting event $(P=0,034, O R$ $=2.22$ ). Stunting is the accumulation of processes or events that can form when the baby is still in the womb (in utero) and lasts up to the age of children 3 years after birth. Stunting is one incidence of malnutrition occurring in children, the predictor of 
a risk that shows poverty, low socioeconomic status, and the prevalence of chronic diseases. Nutritional Status relates to children's physical, mental, social, and intellectual growth ${ }^{11}$. Exclusive breastfeeding in infants allows mothers to provide the first colostrum to the infant. Research in India by Kumar on factors affecting the nutritional status of children also mentions that Colostrum to stunting. Colostrum has a protective effect on the occurrence of disease, such as diarrhea that contributes to malnutrition ${ }^{12}$. Some research results conducted in the Philippines, Indonesia, Bangladesh mention that stunting determinants are three factors, namely child weight, food intake, and infectious diseases that have been suffered, such as diarrhea or infectious diseases in the respiratory. Breast milk as a portion of natural food is the best food that a mother can give to the child she has revealed. Besides the composition suitable for the growth of babies that can change according to the needs breast milk also contains protective substances that can avoid babies from various infectious diseases. Introducing adequate and exclusive breast milk is expected to avoid infectious diseases, which are the risk factors of stunting ${ }^{12}$.

Research on the risk factors that cause obesity in children conducted by the University of Nottingham suggests that a child who obtains exclusive breast milk and is introduced to food other than breast milk for a longer duration has a risk Lower experienced overweight than it does. Results systematic review of the 30 studies that have been done that relate to the risk factors causing obesity in children also become obese that the baby given breast milk (albeit with a short duration) 15\% tend to experience overweight not given breast milk ${ }^{13}$. The relationship between the duration of breastfeeding with a decreased risk of obesity may be caused by various biologic mechanisms. According to Birch and Fisher (1998) in GrummerStrawn and May (2004) There are several possible biologic mechanisms related to the length of the duration of breastfeeding with decreased risk of obesity i.e. the first, children given breast milk can be Regulate the amount of milk they consume, the ability to set up your energy intake is associated with their internal response to realizing better satiety than the children who are given bottled milk ${ }^{14}$. The second possibility is the level of insulin in the blood in children given higher formula milk and has a longer insulin response than the children given breast milk, it stimulates more deposition of fat tissue, which Increases weight, obesity, and the risk of Diabetes mellitus type 2 . The third possibility is the concentration of leptin (a hormone that serves to inhibit appetite and regulate fat in the body) is found in a more balanced concentration in children given breast milk than children who are fed formula. Hypotheses about breastfeeding can cause a protective effect on many obesity, backed by evidence of epidemiology, but are still contortive.

According to Lucas et al in Nguyen (2005), neonatal milk bottles have a change in the concentration of insulin, Motilin, Enteroglucagon, neurotensin, and pancreatic polypeptide in a significant plasma after giving bottled milk. Basal levels of polypeptide Inhibitorik gastric, Motilin, neurotensin, and vasoactive peptide intestinal increased in infants given bottle milk. This may be able to explain the difference in subcutaneous fat deposition and the frequency of defecation between infants given breast milk and those given bottle-feeding ${ }^{14}$. According to Hirai et al Nguyen (2005) Many growth factors contained in breast milk, such as EGF, IGF1, FGF, HGF, and Tgh-Alfa, this has a strong influence on the cells of the intestinal cells and will be influential in the perinatal GI tract adaptation. These growth factors will inhibit adiposity differentiation in vitro. Leptin has a regulatory function in infants by inhibiting appetite and anabolic pathways as well as stimulating catabolic pathways (Casabiel et al in Nguyen, 2005). Breast feeding shows a significant decrease in the risk of obesity in children aged 39 to 42 months (Julie Armstrong, John J Reilly, and the Child Health Information Team, 2003). The provision of breast milk that has many advantages, low side effects, and cheap, is very useful to fight the level of obesity that is ever-increasing in both developed and developing countries ${ }^{14}$.

Administration of complementary food is a short-fat nutrition status risk factor in children aged 12-23 months in Indonesia. This research shows that the child who gets the complementary feeding < 6 months has a higher short-fat nutrition status proportion of $7.1 \%$ compared to the child getting. complimentary feeding $\geq 6$ months $6.3 \%$. Based on the statistical test results there is a meaningful relationship between short-fat with. complimentary feeding in children aged $12-23$ months $(P<0.05)$ with $a$ value of $O R=1.136$ which means that complementary feeding is a short-fat nutrition status risk factor in children aged 12-23 months. Some research results show that there is a significant relationship between the provision of additional food with stunting events. One of the research conducted in Egypt showed that the administration is significantly associated with stunting $(p=0.001 ; O R=1,6){ }^{15}$. for the nutritional needs of infants/children are fulfilled. The provision of. complimentary food needs to note the time of administration of complimentary food, serving frequency, food selection, the way of manufacture, and the way of delivery. At the age of six months, breast milk is no longer enough for infants, so it must be supported by complementary food. If the news is delayed, it will disrupt growth. 
One of them fails to grow at risk of stunting. There is also a deficiency of iron that can cause substances that affect anemia that affects the ability of concentration or learning ability.

Mother's knowledge in providing. complimentary food has a major impact on menu accuracy and time in the administration of complementary food. So that the proper administration can avoid stunting. complimentary food Escort meal needs to be given on time. When done too quickly or slowly, both can cause adverse impacts. When babies are introduced to complimentary food, they can then have a diet that does not fit their body. Babies will get used to eating a lot or excessively. This is what makes babies risky to be obese or obese. There is evidence from the results of the study that the introduction of complementary food before infants aged 4 months (early), 6.3 times at risk of causing obesity. Some studies show that breastfeeding provides a small but consistent protective effect against obesity in children. It has been hypothesized that exposure to the complex sugar and fats contained in the influence of the bottle formula "Obesogenic factor " in infants, which affects the occurrence of obesity in the latter days in life ${ }^{13}$.

This research shows that the child who gets an incomplete immunization has a lower fat short proportion of $5.5 \%$ compared to a child who gets a complete immunization of $7.1 \%$. Based on statistical test results There is a meaningful link between the Fat Short immunization service in children aged 12 23 months $(P<0.05)$ with the value of $O R=0.761$ which means that immunization service is a fat short risk factor in children aged 12-23 months. High immunization coverage is expected to decrease disease incidence are immunized and secondary infections that often occur in the form of pneumonia and diarrhea ${ }^{16}$. Directly infectious diseases affect the problem of nutrition in children so that with the protection of early childhood in children, namely from newborns in the form of immunization can prevent a child early from infected with the hope of children stay healthy so that the growth is not experiencing problems. The results of this research by the results of the research sustainably, DKK, that the basic nutritional status affects the nutritional status (WB/Age). The proportion of children with more nutrients, less or worse found in toddlers with basic immunization status is incomplete compared to the complete immunization status and obtained by very short toddlers is found more $(O R=1.2)$ Children with infants with basic immunization status is incomplete compared to the basic immunization status ${ }^{17}$, so toddler body with basic immunization status is incomplete riskier to be very short $(\mathrm{HB} / \mathrm{A})$ and toddler children with status Incomplete basic immunization are riskier to be thin and very thin. Affects the nutritional status (WB/HB).

This research suggests that a child who does not get vitamin A has a lower fat short proportion of $4.4 \%$ compared to a child who gets vitamin A 7.2\%. Based on statistical test results there is a meaningful relationship between the administration of vitamin A with short fat in children aged $12-23$ months $(P<$ 0.05 ) with the value of $O R=0.601$ which means that immunization service is a fat short risk factor in children aged 12-23 months. Vitamin A is needed by the body, a disease caused by vitamin A deficiency is called Xeropthalmia. The results of this study differ from the research conducted by Karolina E, et.al in 2012 in the Blangkejeren sub-district where the results of the Chi-Square test study showed that there is no meaningful link between giving vitamin A capsules to toddlers with nutritional status based on $\mathrm{WB} / \mathrm{A}$ indicator $(\mathrm{P}=1.000), \mathrm{HB} / \mathrm{A}(\mathrm{P}=0.148)$ and WB/HB $(P=0,063){ }^{18}$. A study similar to the research results of Zahraini (2009) also stated that there is no link between giving vitamin A capsules to toddlers with status Toddler Nutrition. The results of the study can be noted that the family awareness of nutrition based on the indicator of vitamin A capsules in most toddlers is in a good category (95.3\%). This is expected to help children avoid illness caused by less vitamin A (Xeropthalmia) and help increase the body's endurance. This is expected to help children avoid illness caused by less vitamin A (Xeropthalmia) and help increase the endurance of toddler children ${ }^{19}$.

According to Poejiadi (1994), Vitamin A plays a role in the synthesis of mucoproteins and mucopolysaccharides that function to maintain the unity of the epithelium, especially the eye tissue, mouth, breathing apparatus, respiratory equipment, and genital tract. Therefore, if vitamins and minerals are deficient there will be a disturbance of mucosa formation that can cause the body to easily get infected so that it is painless ${ }^{20}$.

\section{CONCLUSION}

The exclusive breast milk factor, administration, immunization services, and vitamin A administration are factors that contribute to the incidence of obese short children. To reduce the short incidence of fat in children need to be done prevention through monitoring of child nutrition status especially monitoring the growth of body length or height based on the age is done early as possible for early detection of nutritional problems in children so that the management can be done quickly to prevent short cases of fat and expected community participation in supporting each program conducted on basic health services. 


\section{ACKNOWLEDGMENTS}

The author would like to thank the family, team members, and institutions who have helped in the completion of this research report. And do not forget to also say thank you to the Research and Development Agency of the Indonesian Ministry of Health who has supported the funding of this research.

\section{REFERENCES}

1. Sihadi. (2012). Kelebihan Berat Badan pada Balita. Retrived from: https://studylibid.com/doc/858458/kelebih an-berat-badan-pada-balita

2. Kemenkes RI. (2013). Laporan Nasional Riset Kesehatan Dasar (Riskesdas).

3. Atmarita \& Fallah S. (2004). Analisis Situasi Gizi dan Kesehatan Masyarakat. Widyakarya Nas Pangan Dan Gizi VIII.

4. Kramer, M.S \& Kakuma R. (2004). The Optimal Duratio Of Exclusive Breastfeeding: Asystematic Review. Adv Exp Med Biol. 2004;5:63-77. DOI : 10.1007/978-1-47574242-8_7

5. Satyawati. MPASI Makanan Pendamping ASI Dapur Ibu. Jakarta: Dian Rakyat; 2012.

6. Siti Nurul Hidayati, R.I. (2006). Obesitas Pada Anak. Divisi Nutrisi dan Penyakit Metabolik, Bagian/SMF Ilmu Kesehatan Anak. FK UNAIR.

7. Kemenkes RI. Pedoman Pemantauan Wilayah Setempat Kesehatan Ibu Dan Anak (PWS-KIA). Jakarta: Direktorat Jenderal Bina Kesehatan Masyarakat Direktorat Bina Kesehatan Ibu; 2010.

8. Ranuh I.G.N, Suyitno H, Hadinegoro S.R.S, Kartasasmita C.B I. Buku Imunisasi di Indonesia Edisi ketiga. 2008.

9. Indonesia Unicef. Ringkasan Kajian Gizi Ibu dan Anak. ; 2012.

10. Beka Teshome, Wambui Kogi Makau, Zewditu Getahun GT. (2009). Magnitude and determinants of stunting in children under five years of age in food surplus region of Ethiopia: The case of West Gojam Zone. Ethiop J Heal . 2009;23 No 2:98-106. https://www.ajol.info/index.php/ejhd/artic le/view/53223.

DOI: $10.4314 /$ ejhd.v23i2.53223

11. Oystein Kravdal dan Ivy Kodzi. (2011). Children's stunting in Sub Saharan-Africa: Is there an externality effect of high fertility. In: Demographic Research [Internet]. 18th ed. Demographic Research; 2011. p. 565-94. http: / / www.demographic-

research.org/Volumes/Vol25/18/\%0A. DOI : 10.4054/DemRes.2011.25.18

12. Kumar D, Goel NK, Mittal PC MP. (2006). Influence of infant-feeding practices on nutritional status of under-five children. Indian J Pediatr. 2006;73(5):417-21. DOI : 10.1007/BF02758565

13. University of Nottingham. (2012). Risk factors predict childhood obesity, researchers find . Retrived from: Www.sciencedaily.com/releases/2012/10/12 1029195200.htm

14. MS Sumardi. (2010). Pengaruh durasi pemberian ASI dengan kejadian obesitas pada Murid PG dan TK A di Yayasan Pendidikan Shafiyyatul Amaliyyah. Repos USU.

15. Amany Edward Seedhom, Eman Sameh Mohammed MD. Eman Mohamed Mahfoudz MD. (2014). Determinants of stunting among preschool children, Minia, Egypt: International Public Health Forum.1(2):6-9 http://www.researchpub.org/journal/iph/ip hf.html

16. Katz SL, Hinman AR. Summary and Conclusions: (2004). Measles Elimination Meeting. J Infect Dis. 189 : Supp I 1:S43-S47.

17. Lestari CSW TE\& S. (2009). Dampak Status Imunisasi Anak Balita di Indonesia Terhadap Kejadian Penyakit. Media Penelit dan Pengembang Kesehat. Volume XIX. https://www.neliti.com/id/publications/15 2453/dampak-status-imunisasi-anak-balitadi-indonesia-terhadap-kejadian-penyakit. DOI : 10.22435/mpk.v0i0.750.

18. Karolina E NE\& AE. (2012). Hubungan Perilaku Kadarzi dengan Status Gizi Balita Usia 12-59 Bulan di Wilayah Kerja Puskesmas Blangkejeren Kecamatan Blangkejeren Kabupaten Gayo Lues.

19. Zahraini Y. (2009). Hubungan Status Kadarzi Dengan Sataus Gizi Balita Usia 12-59 Bulan Di Provinsi DI Yogyakarta Dan Nusa Tanggara Timur. Universitas Indonesia.

20. Anna Poedjiadi, Supriyanti, and F.M. Titin. Dasar-Dasar Biokomia. Jakarta: Universitas Indonesia; 1994. 